\title{
The Use of Mechanical Restraints in Psychiatric Hospitals
}

\author{
Elyn R. Saks $\dagger$
}

Julia, a newly admitted psychotic patient, suddenly breaks a plastic spoon while she is eating lunch. She appears amused, slightly fearful, and a touch defiant. Staff suggest that she needs to be restrained. When Julia resists, six orderlies converge on her, pin her to her bed, and, despite her struggles, cuff her limbs with thick leather straps. Finally, they immobilize her torso with a body net. Tied spread-eagle to the bed, unable to move, Julia is now in "six point" restraints."

In time Julia's physical pain will increase. Her ankles and wrists will bruise, her body will ache from the forced immobility. Although she will beg for release (many patients do), Julia will neither be let go, nor be told when staff plan to untie her. Alone, frightened, and in pain, she will begin to struggle again - a signal to the staff that she needs to be restrained longer. ${ }^{2}$

Julia was a patient in a well-staffed, highly regarded university hospital when this episode occurred. In most jurisdictions, she would not even have a colorable claim that any of her civil rights or liberties had been violated. Her case is by no means unique; in New York state, which has one of the most stringent and carefully written restraints statutes in the country, in a single month's time in 1984, nearly 500 patients were restrained in well over 1,100 incidents. $^{3}$ In fact, Julia was lucky, because she left the hospital unharmed. Between 1979 and 1982, nearly 30 psychi-

$\dagger$ I wish to thank Stephen Behnke for his extensive assistance in the preparation of this Note.

1. "Mechanical restraints" will be used in this Note to refer to the more severe restraining devices, such as "four" and "six point" restraints, body sacks, and camisoles. It will not be used to refer to less severe restraining devices such as arm splints or geriatric chairs, which raise some different issues. This Note takes no position on the acceptability of such devices.

2. For a personal account of a disturbing time in restraints, see C. BEERs, A Mind ThAT Found ITSELF (5th ed. 1921).

3. See Way, The Use of Restraint and Seclusion in NYS Psychiatric Centers: February 15 March 14, 1984 (Dec. 1984), reprinted in N.Y. STATE COMM'N ON Quality OF CARE fOR THE Mentally Disabled \& Mental. Hygiene Med. Rev. Bd., In the Matter of Christopher Dugan, Attachment II, at 1-3 (Jan. 1985) (Executive Summary) (one month study shows 897 individuals in restraints or seclusion and 2,228 episodes of restraint or seclusion in N.Y. facilities; patients with six or fewer episodes, amounting to $95 \%$ of total, studied in greater detail; $54 \%$ in restraints). It is difficult to estimate nationwide how often restraints are used. Only one other incidence study exists: Soloff, Behavioral Precipitants of Restraint in the Modern Milieu, 19 CoMprehensive Psychiatry 179,182 (1978) (3.6\% of patients in two wards of military teaching hospital restrained at least once) [hereinafter cited as Precipitants]. 
atric patients died in New York state from being restrained or secluded. ${ }^{4}$ Ironically, what we allow to happen daily to hundreds of psychiatric patients, we, as a society, would not allow to happen to a person who had committed even the most heinous of crimes. ${ }^{5}$

\section{A Deviation in the Legal Landscape}

Concern for the liberty and dignity of the members of our society permeates American jurisprudence. ${ }^{6}$ Our legal system has spent much effort balancing these extremely personal and highly individual rights against other societal interests. The law's treatment of mechanical restraints deviates sharply from this legal landscape. Compared to the balance struck between other medical interests and patients' interests in liberty and dignity, the rules that govern restraints are disturbing anomalies.

Both the common law and statutes zealously safeguard the liberty and dignity of the patient by protecting the individual's right to choose what is

4. During the four year period between 1979 and 1982,19 patients died in state facilities and 11 in private facilities as a result of being restrained or secluded. $89.4 \%$ of the 19 examined deaths involved restraints only. See Way, Restraint and Seclusion Deaths in NYS Psychiatric Centers: 1979-1982 (Dec. 1983), reprinted in N.Y. State Comm'n On QualtTy of Care For the Mentally Disabled \& Mental. Hygiene Med. Rev. Bd., IN The Matter of Christopher Dugan, Attachment I, at 1, 2 and Table 4 (Jan. 1985).

5. Restraining a prisoner to his bed at four points would seem to be impermissible for either safety or punishment reasons. See, e.g., Spain v. Procunier, 600 F.2d 189, 198-99 (9th Cir. 1979) (tying prisoner to object permitted only in emergency); Pena v. State Division for Youth, 419 F. Supp. 203, 211 (S.D.N.Y. 1976) (restraining youth to furniture impermissible); Gates v. Collier, 349 F. Supp. 881, 900 (N.D. Miss. 1972), affd, 501 F.2d 1291, 1306 (5th Cir. 1974) (enjoining handcuffing to fences, bars, fixtures); Landman v. Royster, 333 F. Supp. 621, 647-48 (E.D. Va. 1971) (chaining prisoner where unable to eat or use toilet, resulting in lack of sleep, pain, and scars, violated Eighth Amendment). The Ninth Circuit has held that restraints may be used on prisoners only in transport, if there is danger, or under medical advice, Spain v. Procunier, 600 F.2d 189, 198-99 (9th Cir. 1979). The Fifth Circuit has declared that they may not be used as a punishment. Ruiz v. Estelle, 666 F.2d 854, 866 (5th Cir. 1982). At least two courts have considered the use of restraints for medical purposes in prisons. See French v. Owens, 538 F. Supp. 910, 919, 928 (S.D. Ind. 1982) (chaining psychotic prisoners spread-eagle to their beds without medication enjoined); Inmates of Allegheny County Jail v. Wecht, 565 F. Supp. 1278, 1284-86 (W.D. Pa. 1983) (restraining women stripped to underwear to cot without mattress unacceptable).

6. Liberty, of course, is explicitly recognized in our Constitution. Dignity has received less formal recognition, but is vital nonetheless. To violate a person's dignity is to pay insufficient regard to his intrinsic worth as a human being. Cruel and unusual punishments do just that; they are so painful or degrading that they demean the human spirit. Thus the Eighth Amendment may be seen as a dignity measure. See Trop v. Dulles, 356 U.S. 86, 100 (1958) (plurality opinion) ("The basic concept underlying the Eighth Amendment is nothing less than the dignity of man."); Furman v. Georgia, 408 U.S. 238, 291 (1972) (Brennan, J., concurring) ("[T]he deliberate extinguishment of human life by the State is uniquely degrading to human dignity."); Glass v. Louisiana, 105 S. Ct. 2159, 2168 (1985) (Brennan, J., dissenting from denial of cert.) (execution by electrocution violates "dignity of man"); Jackson v. Bishop, 404 F.2d 571, 579-80 (8th Cir. 1968) (whipping prisoners violates Eighth Amendment because it violates human dignity of prisoners).

Similarly, common law rules on battery, false imprisonment, and reasonable force all implicate dignity. See, e.g., W. Prosser \& W. Kenton, The LAW of Torts 41 (West 1984) ("The element of personal indignity involved [in batteries] always has been given considerable weight."). See generally id. $\S 9$, at $39, \S 11$, at $47, \S 19$, at 124 , and $\S 20$, at 129 . 
in his own best interests. Except in an emergency, patients have the right under the common law to choose which treatments they will and will not undergo, including the right to elect a treatment that doctors do not believe is the best choice." "Death with dignity" statutes allow a patient to choose even death over what he perceives to be violations of his personal dignity. ${ }^{8}$ And by looking to what the patient would have wanted if competent, rather than to what is medically indicated, certain states guard even an incompetent patient's right to choose medical treatment. ${ }^{9}$ In short, our law has given primacy to individual dignity over medical interests by allowing patients to choose how their dignity will best be preserved. ${ }^{10}$

Givil commitment for mental illness involves issues closely analogous to those implicated in mechanical restraints cases. Like restraints, civil commitment represents "a massive curtailment of liberty,"11 a fact which has led the Supreme Court to hold that certain alleged "treatment-benefits" of commitment (that it affords a patient "milieu therapy," or raises his stan-

7. See generally W. Prosser \& W. Keaton, The Law of Torts \$ 32, at 189-92 (1984). The most helpful work on this subject of informed consent is J. KATZ, THE Sil.eNT WORLD OF DOctor AND PATIENI (1984). Originally, all that was required before a doctor could "touch" a patient was consent. Pratt v. Davis, 118 Ill. App. 161 (1905), affd, 224 Ill. 300,79 N.E. 562 (1906). However, Salgo v. Leland Stanford Jr. University Bd. of Trustees, 154 Cal. App.2d 560, 317 P.2d 170 (1957), introduced the idea that the consent must be informed. See also Natanson v. Kline, 186 Kan. 393,350 P.2d 1093 (1960). This notion was extended in Canterbury v. Spence, 464 F.2d 772, 786-87 (D.C. Cir.), cert. denied, 409 U.S. 1064 (1972) and Cobbs v. Grant, 8 Cal.3d 229, 243, 104 Cal. Rptr. 505, 514,502 P.2d 1, 10 (1972), which introduced the notion that the disclosure standard must be patientbased. The development of the informed consent doctrine has accorded increasing weight to patients' autonomy and dignity; patients must be given enough information to make a decision that best accords with their personal values. Furthermore, in giving this information, doctors must take account of what patients want and need to know, not of what other doctors think it medically best for them to know. See also Katz, Informed Consent-A Fairy Tale? Law's Vision, 39 U. PITT. L. Rev. 137 (1977); Plante, An Analysis of "Informed Consent," 36 FordhaM L. Rev. 639 (1968). For a strong defense of patient autonomy, see Shultz, From Informed Consent to Patient Choice: A New Protected Interest, 95 YAl.F. L.J. 219 (1985).

8. See, e.g., Freeman, Death with Dignity Laws: A Plea for Uniform Legislation, 5 SeTon Hall LEcis. J. 105 (1982); Martyn \& Jacobs, Legislating Advance Directives for the Terminally Ill: The Living Will and Durable Power of Attorney, 63 NEB. L. REv. 779 (1984).

9. For the substituted judgment standard as used in the case of the mentally ill, see, e.g., Rogers v. Comm'r of Mental Health, 390 Mass. 489, 458 N.E.2d 308, 315 (1983) ("The recognition of that right [to refuse treatment] must extend to the case of an incompetent, as well as a competent, patient because the value of human dignity extends to both. . . .") (quoting Superintendent of Belchertown State School v. Saikewicz, 373 Mass. 728, 745, 370 N.E.2d 417, 427 (1977)); In re Boyd, 403 A.2d 744, 750-51 (D.C. 1979). Notice that a "best medical interests" standard rather than a "substituted judgment" standard may reflect a judgment that searching for a patient's competent wishes is generally fruitless, and most patients want what their doctors advise anyway, rather than a judgment that a patient's medical interests are more important than his dignity interests.

10. Religious values have also been held to supersede medical interests, sometimes even if refusal of treatment will mean death. See In re Osborne, 294 A.2d 372, 374-75 (D.C. 1972). Religious refusals of treatment are more commonly upheld when death is not an issue, however. For cases where the patient is mentally ill, see Winters v. Miller, 446 F.2d 65 (2d Cir.) cert. denied, 404 U.S. 985 (1971) (Christian Scientist has right to refuse psychotropic medication), and Osgood v. District of Columbia, 567 F. Supp. 1026 (D.D.C. 1983) (same).

11. Humphrey v. Cady, 405 U.S. 504, 509 (1972). 
dard of living) are constitutionally insufficient to justify commitment. ${ }^{12}$ Most states have gone even farther. They have forbidden commitment for the sake of any kind of treatment at all, ${ }^{13}$ and have limited it solely to those who are dangerous to themselves or others or who are gravely disabled. Only in these extreme circumstances are liberty and dignity violations believed to be justified.

Accordingly, substantial procedural protections accompany civil commitment to ensure that the infringement upon an individual's dignity and liberty is justified. ${ }^{14}$ To determine whether patients meet the commitment criteria, most states entitle patients to a hearing: ${ }^{15}$ to notice, to a right to confront and cross examine witnesses, and to representation by counsel. ${ }^{18}$ Moreover, the Supreme Court has held that patients must be found to meet the commitment criteria by "clear and convincing" evidence. ${ }^{17}$ Mandatory review procedures are common. ${ }^{18}$

A substantial majority of states also apply a "least restrictive alternative" mandate to civil commitment, requiring that any infringement upon a patient's liberty must be the absolute minimum necessary to achieve the

12. See O'Connor v. Donaldson, 422 U.S. 563 (1975). The Court did not reach the issue of whether treatment in general justifies commitment, id. at 573 , but it did consider these particular alleged "treatment benefits." The court below had found that milieu therapy in this case was nothing more than confinement in the milieu of the hospital-not enough treatment to justify the patient's injuries. Id. at 569. And if treatment is a defense to commitment, then whether something is treatment is justiciable. Id. at 574 n.10. Moreover, the "mere presence of mental illness," the Court found, "does not disqualify a person from preferring his home to the comforts of an institution," id. at 575. The Court found a person's desire for freedom more important than the material gains provided by institutionalization.

13. As of 1974, only 17 states still allowed commitment based on the "need for treatment" alone. See Note, Developments in the Law: Civil Commitment of the Mentally Ill, 87 Harv. L. REv. 1190, 1201-07 (1974) [hereinafter cited as Developments].

14. But of. Parham v. J.R., 442 U.S. 584 (1979), which gives children fewer procedural protections than adults. Parham also seems to give doctors more authority, and to view commitment as more a medical decision, than did O'Connor $v$. Donaldson. But in Parham the determination that doctors are called on to make-that the child is mentally ill and could benefit from hospital treatment-is a medical determination, while the value-decision of whether the benefits of treatment are worth the detriments of hospitalization has already been made by the parents. The parents have decided that their child's being "in need of treatment" is a good enough reason for hospitalization.

15. As of 1974 , only ten states used administrative, rather than judicial, hearings to make this determination (although some provided for judicial hearings as an alternative). See Developments supra note 13 , at 1269 n.36.

16. On notice, see, e.g., Conn. Gen. Stat. § 17-178(a) (1985); Iowa Code AnN. § 229.7 (West 1985); Mont. CODE ANN. § 53-21-121(3) (1983); WAsh. Rev. Code ANN. § 71.05.460 (1975). On the right to cross-examine, see, e.g., ConN. GEN. Stat. $\S 17-178(c)$ (1985); Iowa Code ANN. $\S$ 229.12(1) (West 1985); MoNT. Code ANN. § 53-21-126(3) (1983); Wash. Rev. Code ANN. $\S$ 71.05.200(1)(d) (1975). On the right to appointed counsel, see, e.g., ConN. Gen. STAT. \& 17-178(b) (1985); Iowa Code ANN. § 229.8(1) (West 1985); Mont. Code ANN. § 53-21-122(3) (1983); WASH. Rev. CODE ANN. \$ 71.05.460 (1975).

17. Addington v. Texas, 441 U.S. 418 (1979).

18. Most states require periodic judicial review of commitment decisions. See, e.g., ConN. GEN. Stat. § 17-178(g) (1985); Mont. Code ANN. § 53-21-128(2) (1983); S.D. Codified Laws ANN. § 27A-12-17 (1984); WASh. Rev. CoDE ANN. \$ 71.05.320(2) (West 1986). Of course, habeas corpus review is available to anyone who believes he or she is illegally committed. 
state's end. ${ }^{19}$ These least restrictive alternative statutes are in keeping with the long-articulated principle that intrusion upon an individual's constitutional rights will be permitted only to the extent necessary to achieve another legitimate state interest. ${ }^{20}$

One area, however, in which some courts and legislatures have been striking the balance in favor of the state interest has been the field of psychotropic medication. Patients' choices not to have psychotropic medication have been overridden in these jurisdictions not only in situations of danger, but also when the treatment-benefits have been deemed great enough, ${ }^{21}$ such as when there are no other less intrusive ways to bring about improvement or when other treatments will take significantly longer to be effective. ${ }^{22}$ In reaching these decisions, the jurisdictions have given great weight to the vast and largely undisputed literature which asserts that medication is a very effective treatment for most major mental illnesses. ${ }^{23}$ But even here-where nearly the entire medical community

19. Least restrictive alternative mandates have been incorporated into at least twenty state statutes explicitly, and fourteen implicitly. See Note, The Right to Treatment in the Least Restrictive Alternative: The Confusion Remains After Youngberg v. Romeo, 19 NEw ENG. L. REv. 175, 182-88 (1983) (twenty states have least restrictive alternative mandate explicitly, fourteen, implicitly); see also Hoffman \& Foust, Least Restrictive Treatment of the Mentally Ill: A Doctrine in Search of its Senses, 14 San Diego L. Rev. 1100 (1977); Comment, The Scope of the Involuntarily Committed Mental Patient's Right to Refuse Treatment with Psychotropic Drugs: An Analysis of the Least Restrictive Alternative Doctrine, 28 VILL. L. REv. 101 (1982).

20. Historically, this doctrine has been applied to cases involving the First Amendment, see, e.g., Shelton v. Tucker, 364 U.S. 479, 488 (1960) (right of association); the due process clause, see, e.g., Griswold v. Connecticut, 381 U.S. 479, 485 (1965) (right of privacy); and the equal protection clause, see, e.g., Dunn v. Blumstein, 405 U.S. 330, 343 (1972) (right to vote). The doctrine has also been extended to the mental health context. See, e.g., Lake v. Cameron, 364 F.2d 657, 660 (D.C. Cir. 1966) (civil commitment); Covington v. Harris, 419 F.2d 617, 623-25 (D.C. Cir. 1969) (intrahospital disposition to high security ward); De Angelas v. Plaut, 503 F. Supp. 775, 781 (D. Conn. 1980) (civil commitment of incompetent accused). The constitutional status of the doctrine in the mental health context, however, is uncertain in light of the failure of Youngberg v. Romeo, 457 U.S. 307 (1982), to adopt the least restrictive alternative analysis of the lower court.

21. A small number of states expressly allow involuntary psychiatric medication of patients without providing a standard for when such action is acceptable. See, e.g., AlASKA STAT. $\$ 47.30 .772$ (1984); ARK. Stat. ANN. § 59-1415(2) \& (4) (Supp. 1985); ConN. Gen. Stat. § 17-206d(b) (1985).

22. See, e.g., Delaware Department of Health and Social Services, Division of Mental Health, Delaware State Hospital Policy $\S 1.50$ (1985) (on file with author) (hereinafter cited as Delaware State Hospital Policy \$ 1.50]; Michigan Department of Mental Health, Public Mental Health Manual: Administration of Psychotropic Medication and For Protection of Recipients' Rights 6 (Aug. 2, 1984) [hereinafter cited as Michigan Administration of Psychotropic Medication]; N.J. Reg § II(2)(a) \& (b); North Carolina Department of Human Resources, Division of Mental Health, Mental Retardation, and Substance Abuse Services, Human Rights for Clients of State Owned and Operated Facilities, APSM 95-1, at J. 0400-1 to J.0400-2 (1984) [hereinafter cited as North Carolina, Human Rights].

23. See, e.g., Appleton, Fourth Psychoactive Drug Usage Guide, 43 J. Clin. Psychistry 12 (1982); R. Baldessarini, Chemotherapy in Psychiatry (1985); L. Kolb \& H. Brodie, Modern Clinical Psychiatry 809 (10th ed. 1982); D. Morgan, Psychopharmacology: Impact of Clinical. Psychiatry (1985); Guidelines for the Use of Psychotropic Drugs (H. Stancer, P. Garfinkel \& V. Rakoff eds. 1984). 
agrees upon the efficacy of psychotropics-a number of states have adopted procedural protections governing involuntary medication. ${ }^{24}$

From these four areas of law, it is possible to draw four general principles which seem to guide society's balance of medical interests against a patient's liberty and dignity interests. First, a patient should be deprived of his liberty only when failure to do so either presents a risk of serious physical harm to himself or others or prevents medical treatment which has clearly been shown to be effective. Second, a patient should be deprived of his liberty only to the extent necessary to achieve the desired goal. Third, a patient's right to choose among treatments should be protected wherever possible. Fourth, when a patient must be deprived of liberty, a set of strict procedures should be imposed to ensure that the infringements upon his liberty and dignity will be kept to an absolute minimum.

The law's current treatment of restraints substantially departs from these principles. Most states allow hospital staff to put patients in restraints when there is no serious threat of injury and without any clear showing of their efficacy. ${ }^{25}$ Little effort is made to ensure that only that

24. A number of states provide for review by statute. See, e.g., IND. CoDE ANN. § 16-14-1.6-7 (Burns 1983); Ky. Rev. Stat. AnN. § 202A.196 (Baldwin 1985); Md. Health-General Code ANN. § 10-708 (Supp. 1985). A number of other states provide for review in regulations or policy directives. See, e.g., Delaware State Hospital Policy $\$ 1.50$ (1985), supra note 22; Michigan Administration of Psychotropic Medication, supra note 22; North Carolina, Human Rights, supra note 22; TeX. Admin. Code tit. 25, § 405.808 (1984).

25. Most state restraints statutes do not use a dangerousness standard. Restraints statutes may be divided into seven categories. First is the statute that requires the use of restraints to be recorded: $W$. VA. CODE \$27-5-9(c) (1980).

Second are the statutes that proscribe unnecessary or excessive restraints: ARK. STAT. ANN. $\$ 59$ 1416(23) (Supp. 1985); Ky. REv. STAT. ANN. § 202A.191(h) (Baldwin 1985); N.D. Cent. Code § 25-03.1-40(4) (1978); VA. CODE $\S 37.1-84.1(6)$ (1984).

Third are the statutes that require restraints to be prescribed by a designated authority, usually a physician: D.C. CODE ANN. § 21-563 (Supp. 1985); NEv. Rev. StAT. § 433.484(2) (1985); OHIO Rev. Code Ann. § 5122.27(F)(7) (Page 1981); Tex. Rev. Civ. Stat. Ann. art. 5547-86 (Vernon 1986).

Fourth are the statutes that allow restraints only if required by the "medical needs" of the patient: ME. Rev. Stat. ANN. tit. 34-B, § 3803(3) (Supp. 1985); OkLA. Stat. Ann. tit. 43A, § 92 (West 1979); OR. Rev. STat. § 426.385(3) (1985); PA. Stat. Ann. tit. 50, § 4422 (Purdon 1969); S.C. Code ANN. § 44-23-1020 (Law. Co-op. 1985); TrnN. Code ANN. § 33-3-104(4) (Supp. 1985); Utah CODE ANN. § 64-7-47 (Supp. 1985); VT. Stat. ANN. tit. 18, § 7704 (1968); Wyo. Stat. § 25-10-119 (1982).

Fifth are the statutes that allow restraints, roughly, for either safety in an emergency or on a professional's written order explaining the rationale for the restraint: MONT. CoDE ANN. § 53-21146 (1983); N.J. Stat. ANN. 30:4-24.2(d)(3) (West 1981); S.D. Codified Laws ANN. § 27A-12-6 (Supp. 1986).

Sixth are the statutes that allow restraints, roughly, for either the safety or the treatment of the patient: Ariz. Rev. Stat. ANN. § 36-513 (1986); HAwaIr Rev. STAT. § 334E-2(18) (Supp. 1980); Ind. CODE ANn. § 16-14-1.6.6 (Burns 1983); LA. Rev. StAt. ANn. § 28:171(D) (West Supp. 1986); Mich. Comp. Laws ANN. § 330.1742(2) (West 1980) (seclusion); N.G. GeN. STat. § 122G60 (Supp. 1985); Wis. Stat. AnN. § 51.61(1)(i) (West Supp. 1985).

Seventh are the statutes that do require dangerousness to self or others: Alaska STAT. § 47.30.825(d) (1984); ConN. GEN. Stat. § 17-206e(a) (1985); GA. Code AnN. § 37-3-165 (Supp. 
amount of restraint is exercised which is required to achieve the desired end, ${ }^{26}$ and, as a matter of course, patients are given no choice in the manner of restraint. ${ }^{27}$ Finally, few, if any, procedural safeguards attend the patient's initial deprivation of liberty, or are called into play to determine how long the deprivation will continue. ${ }^{28}$ Overall, current law overwhelmingly sees restraints as a practice best regulated by internal professional norms, and thus leaves to doctors and hospital staff most decisions about how restraints are to be used. ${ }^{29}$

\section{Is a Laissez-Faire Policy Justified?}

Three reasons may be offered in defense of the law's laissez-faire attitude toward the use of mechanical restraints: first, that the medical benefits derived from their use justify the intrusion into patients' liberty and dignity; second, that the mentally ill do not have as great an interest in liberty and dignity as do other patients; third, that a strict legal standard governing the use of restraints would be too great an intrusion into medical institutions. A close examination of each of these reasons indicates that none warrants the law's "hands-off" policy toward the use of mechanical restraints.

1985); Idaho Code $\S 66-345$ (Supp. 1986); It.L. Rev. Stat. ch. 91 12/2, § 2-108 (1982); Kan. Stat. ANN. § 59-2928 (1983); MD. Health-Genfrai. Cone ANN. § 10-701(c)(3) (Supp. 1985); Mass. Gen. Laws $\Lambda$ NN. ch. 123, § 21 (West Supp. 1985); Mrch. Comp. Laws Ann. $§ 330.1740$ (West 1980) (restraints); Minn. Stat. ANN. § 253B.03(1) (West 1982); Mo. ANN. Stat. $§ 630.175$ (Vernon Supp. 1986); N.Y. Mental. Hyg. Law $\$ 33.04$ (Consol. 1978). See also Tardiff \& Mattson, A Survey of State Mental Health Directors Concerning Guidelines for Seclusion and Restraint in The Psychiatric: Ustes of Seclusion and Restraint 141, 144 (K. Tardiff ed. 1984) [hereinafter cited as Uss:s] (21 states have regulations that allow restraints only to prevent harm to self, others, or property, but some may not apply state-wide). These statutes, however, contain inadequate procedures and other deficiencies. See infra notes 71-85 and accompanying text.

26. No statute adequately distinguishes between restraints and seclusion, resulting in the use of restraints even when there are less restrictive alternatives. See infra note 76 . The proposal below does limit restraints to when they are the least restrictive alternative. See infra notes 72-77 and accompanying text.

27. Only two states mention the issue of choice. Oklahoma allows patients to choose seclusion or restraints over medication (but not vice versa) "if practical." OKLA. STAT. ANN. tit. 43A, §54.8D (West Supp. 1985). Alaska requires that the patient's choice among forms of restraint be consulted and "considered," if "practicable." Alaska STAT. $§ 47.30 .825$ (d) (1985). The proposal below, see infra notes 78-80 and accompanying text, goes beyond these statutes.

28. See infra notes 81-83.

29. In Youngberg v. Romeo, 457 U.S. 307, 321-23 (1982), the Supreme Court decided that the constitutional standard is an "actual professional judgment" standard. Existing common law restraints cases rely on a malpractice standard, which is also based on professional norms. See Annot., 8 A.L.R.4th 509, $512 \S \S 13,15$ (1981); 25 A.L.R.3d 1450 (1969). 


\section{A. Casting Doubt on Treatment Efficacy: The British Experience}

A comparison of British and American practices governing the use of restraints raises serious doubts about the alleged "medical benefits" offered by mechanical restraints.

The American medical community readily accepts the use of physical controls. ${ }^{30}$ American psychiatrists do not even see mechanical restraints as a "regrettable but permissible emergency liberty infringement." R1 Rather, in their view, restraints can be justified by one of two "medical benefits" theories: they are either a form of therapy (the "treatment" view) or a form of patient management, with medical indications and contraindications (the "management" view). ${ }^{32}$

30. Although this Note focuses on restraints, and discusses seclusion and emergency medication only insofar as they bear upon the use of restraints, in discussions of the theory and practice of restraints, some reference will be made to the more voluminous literature on seclusion. Seclusion is different from restraints in some respects: it may be used for destimulation, and it may result in sensory deprivation. If care is taken to except these features, however, the literature on seclusion can be helpful, for seclusion and restraints share the important feature of limiting destructive behavior, and may be presumed to have similar causes and effects. Some commentators go so far as to suggest that seclusion and restraints are interchangeable, see infra note $80 \rightarrow$ not a position held in this Note. Moreover, restraints often take place in seclusion; thus a knowledge of seclusion is helpful to an understanding of restraints.

31. Gutheil \& Tardiff, Indications and Contraindications for Seclusion and Restraint, in UsEs, supra note 25 , at 11 .

32. For some of the most important discussions in favor of the use of restraints and seclusion, see, e.g., The. Psychiatric Uses of Seclusion and Restraint, supra note 25 (discussing restraints and seclusion in wide variety of contexts, e.g. use on the psychiatrically ill, the elderly, and the developmentally disabled); Bursten, Using Mechanical Restraints on Acutely Disturbed Psychiatric Patients, 26 HosP. \& CoMm. PsychinTRy 757 (1975) (giving indications for use of restraints); Rosen \& DiGiacomo, The Role of Physical Restraint in the Treatment of Psychiatric Illness, $39 \mathrm{~J}$. CuIN. Psychistry 228 (1978) (same). The most important discussion opposing the use of restraints is Guirguis, Management of Disturbed Patients: An Alternative to the Use of Mechanical Restraints, 39 J. Clin. Psychiatry 295 (1978) (discussing disadvantages of use of restraints).

See also Cubbin, Mechanical Restraints: To Use or Not to Use? 66 NuRsING Times 752 (1970); Fitzgerald \& Long, Seclusion in the Treatment and Management of Severely Disturbed Manic and Depressed Patients, 11 Psychiatric Care 59 (1973); Gair, Limit-Setting and Seclusion in the Psychiatric Hospital, Psychiatric OPINION, Feb. 1980, at 15; Gutheil, Observations on the Theoretical Bases for Seclusion of the Psychiatric Inpatient, 135 AM. J. Psychiatry 325 (1978); Gutheil, Restraint Versus Treatment: Seclusion as Discussed in the Boston State Hospital Case, 137 AM. J. Psychiatry 718 (1980); Kilgalen, The Effective Use of Seclusion, J. Psychiatric NuRsing \& Mental. Health Services Jan. 1977, at 22; Assault wirhin Psychiatric Facilrties (J. Lion \& W. Reid eds. 1983); Plutchik, Karasu, Conte, Siegel \& Jerrett, Toward a Rationale for the Seclusion Process, $166 \mathrm{~J}$. Nervous and Mental Disease 571 (1978) [hereinafter cited as Plutchik]; Reid, Controlling the Fight/Flight Patient, Can. Nurse Oct. 1973, at 30; Clinical Treatment of THE: Violent Person (L. Roth ed. 1985); Soliday, A Comparison of Patient and Staff Attitudes toward Seclusion, 173 J. Nervous \& Mental Disease 282 (1985); McElroy, Consumers of Psychiatric Services and Staff: Worlds Apart on the Issue of Seclusion, $173 \mathrm{~J}$. NERvous \& MENTAL Disease 287 (1985); Chamberlin, An Ex-Patient's Response to Soliday, $173 \mathrm{~J}$. Nervous \& Mental. Disease 288 (1985); Jensen, Comments on Dr. Stanley M. Soliday's "A Comparison of Patient and Staff Attitudes toward Seclusion," 173 J. Nervous \& Mental Disease 290 (1985); Soloff, Physical Restraint and the Nonpsychotic Patient: Clinical and Legal Perspectives, $40 \mathrm{~J}$. Cl.In. Psychiatry 302 (1979) [hercinafter cited as Restraint and the Nonpsychotic Patient]; Strutt, Bailey, Peermohamed, Forrest \& Corton, Seclusion: Can It Be Justified?, 76 Nursing Trmes 1629 (1980) [hereinafter cited as Strutt]. 
The "treatment" view ${ }^{33}$ sees restraints as therapy for psychotic patients who are disorganized, delusional, and often impulsive. Restraints are supposed to calm these patients by reassuring them that they will not be allowed to lose control, ${ }^{34}$ and are said to "give definition [to] disrupted egoboundaries." 35 The literature analogizes the restraining process to a mother holding her crying, kicking child until the child is able to regain control. $^{36}$

Under the "management" view, restraints are indicated to prevent violence, to calm agitated patients, and to preserve the "therapeutic milieu." ${ }^{37}$ In practice, restraints are most often used for the latter two reasons. ${ }^{38}$ Management theorists recommend that restraints be used at the earliest sign of disturbance. ${ }^{39}$

For discussions of the legal issues raised by seclusion and restraints, see Wexler, Seclusion and Restraint: Lessons from Law, Psychiatry, and Psychology, 5 INT'L J. L. \& Psychistry 285 (1983) (discussing implications of Youngberg $v$. Romeo for restraint and seclusion practices) ; Wexler, Legal Aspects of Seclusion and Restraint, in USFs, supra note 25, at 111 (same) [hereinafter cited as Legal Aspects]; Dix, Legal and Ethical Issues in the Treatment and Handling of Violent Behavior, in Clinical. Treatmint of the Violent Person, supra, at 187 (discussing issues raised by emergency and behavior modification uses of restraints and seclusion).

33. Several commentators state or suggest that restraints are a form of "treatment." See, e.g., Straker, Guidelines for the Elderly, in USES, supra note 25, at 103. Nowhere in the literature on restraints is this treatment theory spelled out, however. This Note therefore borrows from the literature on seclusion, as well as from discussions with numerous professionals, to piece together the "treatment" view of restraints.

This treatment view of restraints is not new. In the past restraints were thought to torture patients out of "their madness," see Three Hundred Years of Psychiatry 254 (R. Hunter \& I. MacAlpine eds. 1963) (section discussing and quoting F. van Helmont) (hereinafter cited as 300 YEARS]; Three Hundred Years of Psychiatry 325 (R. Hunter \& I. MacAlpine eds. 1963) (section discussing and quoting P. Blair), or to suppress physical excitement and thereby tranquilize the mind, see Three Hundred Years of Psychiatry, 473, 478 (R. Hunter \& I. MacAlpine eds. 1963) (section discussing and quoting W. Cullen).

Even pro-restraints theorists have long been aware that restraints can put patients in a more disturbed state of mind. See Reid, supra note 32, at 33; Kronberg, in Assault within Psychiatric FAcilitirs, supra note 32, at 23; Rosen \& DiGiacomo, supra note 32, at 232; Mattson \& Sacks, Seclusion: Uses and Complications, 135 AM. J. Psychiatry 1210, 1212 (1978). Opponents of restraints, such as Guirguis, think that exacerbation of disturbance is the usual result of restraints. See Guirguis, supra note 32, at 297. See also Conolly, infra note 42.

34. See, e.g., Kilgalen, supra note 32, at 24; Soloff, Precipitants, supra note 3, at 180; Wells, The Use of Seclusion on a University Hospital Psychiatric Floor, 26 ARCH. Gen. Psychiatry 410, 412 (1972).

35. See Soloff, Restraint and the Nonpsychotic Patient, supra note 32, at 302; see also Soloff, Precipitants, supra note 3, at 188; Soloff, Physical Controls: The Use of Seclusion and Restraint in Modern Psychiatric Practice, in Clinical Treatment of the Violent Person, supra note 32, at 124, 129 [hereinafter cited as Physical Controls]. In a related vein, Soloff also sees restraints as bringing about the restitution of internal controls. See Soloff, Restraint and the Nonpsychotic Patient, supra note 32 , at 305 .

36. See Reid, supra note 32, at 32; Gair, supra note 32, at 15-16.

37. See Gutheil \& Tardiff, supra note 31 , at 11-12. The "therapeutic milieu" is that atmosphere of the ward which is supposed to be therapeutic for patients. Simply stated, "preserving the milieu" means maintaining calm on the ward.

38. See, e.g., Gutheil, Review of Quantitative Studies, in Uses, supra note 25, at 125, 130-37; Soloff, Physical Controls, supra note 35, at 129-35.

39. See Gutheil \& Tardiff, supra note 31 , at 11. 
On both the "treatment" and "management" views, then, it is clear that restraints are recommended for earlier and longer use than they would be for safety reasons alone. ${ }^{40}$

In contrast to their American counterparts, British psychiatrists have successfully done without the major forms of mechanical restraint for many years. ${ }^{41}$ The non-restraint movement in Britain was begun by John Conolly in the last century, ${ }^{\mathbf{2}}$ and today's British psychiatrists recommend using physical controls (like seclusion) only when absolutely necessary,

40. For the "management" theorist's position, see id. For the "treatment" theorist's position, see Rosen \& DiGiacomo, supra note 32 , at 230-31.

41. Although the British do still use minor restraining devices such as arm splints and geriatric chairs, they do not employ the major forms of restraint. See British Mental Health Act Commission, Patients Presenting Particular Management Problems § 8.6.1 (Proposed Regulations) (on file with author). These recommendations of the Mental Health Act Commission, a body established to write a Code of Practice for psychiatrists, will be submitted to the Secretary of State, who will "consult such bodies as appear to be concerned" and then lay the proposals before Parliament. See Mental Health Act 1983, at $\$ 118$ (3) \& (4), 1983 Pub. Gen. Acts \& MeAs. ch. 20. While Patients Presenting Particular Management Problems $\S 8.6 .1$ prescribes procedures to be used in the case of the minor restraining devices, this proposed regulation also states that: "In Britain, major forms of mechanical restraint have long been abandoned. . . ." The Mental Health Act Commission has stated that "major forms of mechanical restraint" include manacles, straightjackets, and four point restraints. Letter from Mental Health Act Commission (Feb. 20, 1986) (on file with author). See also Dewhurst, The New Methods of Restraint, 66 Nursing TIMes 749, 751 (1970) (finding no evidence that major forms of restraint, including posey vest and four points, used in British psychiatric hospitals).

42. Conolly was the most famous spokesperson for the non-restraint movement in Britain. His book, The Treatment of The INSANE without Mechanical. Restraints (1856), thoroughly documented the salutary effects of removing patients' shackles. Although Conolly did allow for the use of seclusion in some circumstances, $i d$. at 212, 232-33, he recommended a policy of forbearance toward patients' inappropriate behavior, id. at $235,40,115-16$, and managed to forego the use of restraints for over ten years. His accomplishment was even more remarkable in that he did not have antipsychotic drugs with which to calm his patients. Moreover, contrary to what Soloff suggests in Physical Controls, supra note 35, at 125-26, Conolly's hospital did care for acute as well as chronic patients; see, e.g., ThF Trfatment of ThE InSane Without Mechanical Restraints (1856), at $35-37,224-25$, and 262 . Forty other large public asylums quickly replicated Conolly's success. Id. at 342.

Conolly did have some predecessors. Philippe Pinel began the non-restraint movement in Europe in 1793. R. Hill experimented with the total abolition of restraint at the small hospital in Lincoln, England: "in a properly constructed building, with a sufficient number of suitable attendants, restraint is never necessary, never justifiable, and always injurious, in all cases of Lunacy whatever." See 300 YkARs, supra note 33, at 890 (emphasis in original); see also id. at 897 (discussing and quoting Prichard, credited by Hill as first person to adopt non-restraint system in full); Knoff, Modern Treatment of the "Insane": An Historical View of Nonrestraint, 60 N.Y.S. J. MED. 2236 (1960); Soloff, Historical Notes on Seclusion and Restraint, in UsEs, supra note 25, at 1.

For accounts of more recent efforts to reduce the use of restraints and seclusion in America, see Greenblatt, Seclusion as a Means of Restraint, Psychiatric OpInion, Feb. 1980, at 13; Solomon, Half a Century of Hospital Psychiatry, 19 Hosp. \& CoMm. Psychiatry 367 (1968). See also M. Greinblatt, R. York \& E. Brown, From Custodial to Therapeutic Care in Mental Hosprrais 60, 307 (1955) (patient hours in seclusion dropped from over 600 hours a month to under 50 hours a month within two and a half years at one hospital; from 265 hours a week to one hour a week within four months at another hospital); Jacoby, Babikian, McLamb \& Hohlbein, A Study in Non-Restraint, 115 AM. J. PsYchiatry 114, 119 (1958) (40 patients in restraints a day to zero a day in six weeks; no seclusion used). While these studies show that American hospitals are able to reduce the use of seclusion and restraints, despite their initial pessimism about the process, comparison with the British experience suggests that American hospitals still have a long way to go. 
and then only to the smallest possible degree.43 For example, a British Commission has recommended that using physical controls to preserve the milieu in British hospitals be forbidden.4

The statistics demonstrate the success of the British philosophy. Despite the absence of mechanical restraints, the British use seclusion less often than American psychiatrists, ${ }^{45}$ and there is no evidence that they use medication or physical restraint ${ }^{48}$ more than American psychiatrists. ${ }^{47}$ Indeed, the British mental hospital today uses little coercion of any kind; most

\section{As the Royal College of Psychiatrists says:}

The degree of force should be the minimum required to control the violence and it should be applied in a manner that attempts to reduce rather than provoke a further aggressive reaction. The number of staff involved should be the minimum necessary to restrain the patient while minimising injury to all parties.

British Department of Health and Social Security, Health Services Management: The Management of Violent, or Potentially Violent, Hospital Patients, Health Circular HC[76]11, Appendix by Royal College of Psychiatrists. Compare Lion \& Soloff, Implementation of Seclusion and Restraint, in USES, supra note 25, at 19,23 (discussing American psychiatry's recommendation of "show of force" as best means of averting or minimizing violence). Similarly, British Mental Health Act Commission, Patients Presenting Particular Management Problems (Proposed Regulations) (on file with author) clearly and cogently states a minimalist approach to the use of physical controls.

For further examples of British seclusion guidelines, see Royal College of Nursing, Seclusion and Restraint in Hospitals and Units for the Mentally Disordered (April 1979) (on file with author); Nursing Management Directive: Seclusion-The Use of Single and Protective Rooms, No. 3 (April 1984) (on file with author); Royal College of Psychiatrists, Locking up Patients By Themselves, 6 Bull. Royal College of Psychiatrists 199 (1982). See also Royal College of Psychiatrists, Isolation of Patients in Protected Rooms During Psychiatric Treatment, 5 Bull. RoYal College of PsychiATRISTS 96 (1981).

44. See British Mental Health Act Commission, Patients Presenting Particular Management Problems \$8.2 (Proposed Regulations) (on file with author): "Both informal and detained patients may exhibit behaviour other than violence which may cause management problems. This may include irresponsible behaviour; un-cooperativeness; socially embarrassing behaviour; sexually inappropriate behaviour; aimless wandering; self-injury. Only close supervision, individual plans of care, and a suitable setting or environment should be used for such behaviour."

45. For British seclusion rates, see Strutt, supra note 32, at 1632 (average secluded in month: .26\%; maximum time: 2 hours and 40 minutes); Mental Health Act Commissioner, The Practice of Seclusion in Psychiatric Hospitals (on file with author) (only 35 of 42 public hospitals use seclusion; average time: one half hour to an hour); Higgins, Four Years' Experience of an Interim Secure Unit, 282 BRIT. MED. J. 889, 890 (1981) (seclusion used for only "a few hours in four years" in facility for most difficult patients). But of. Campbell, The Use of Seclusion, 78 NuRsing Times 1821, 1822-23 (1982) (seclusion used on $75 \%$ of patients; still, average only 2.6 hours, maximum, 23 hours; year long study with no control for days at risk). Compare American rates, cited in Gutheil, Review of Quantitative Studies, supra note 38, at 126-27 (range from $1.9 \%$ to $44 \%$, with an average of $18.8 \%$; range in average times from less than three hours to 20 hours, with an average of 9.7 hours).

On restraints rates in America, see supra note 3. But note also that in Schwabb \& Lahmeyer's study, The Uses of Seclusion on a General Hospital Psychiatric Unit, 42 J. CLIN. Psychistry 228, 230 (1979), 18\% of the patients in seclusion were also in restraints, and that in Tardiff's study, Emergency Control Measures for Psychiatric Inpatients, $169 \mathrm{~J}$. Nervous \& MeNTAL Disease 614, 615 (1981), the figure of $1.9 \%$ refers to patients in seclusion or restraints.

46. "Physical restraint" means holding a patient down but not tying him up.

47. Nor is there evidence that the British have a higher rate of injuries as a result of not using restraints. Indeed, the evidence that restraints prevent violence is somewhat equivocal: half of all assaults on staff in American psychiatric hospitals occur during restraint and seclusion episodes. See Lion \& Soloff, supra note 43, at 22, citing Assault wrrhin Psychiatric Facilities, supra note 32. Restraints and seclusion may so frighten or anger some patients that they are likelier to become violent: 
wards are unlocked, and voluntary patients-the vast majority-are free to leave the hospital without notice. ${ }^{48}$

That British psychiatrists so vigorously oppose the use of mechanical restraints, and that they care for their patients with little recourse to them, calls the American "treatment" view into doubt. Indeed, the evidence in favor of the efficacy of restraints is at best anecdotal, ${ }^{49}$ and even proponents of the "treatment" view would be hard-pressed to claim that this evidence is anything like that in favor of psychotropic medication. If it is permissible to deprive a patient of his liberty for treatment purposes only when the benefits of the treatment are clear, then the "treatment" rationale for the use of restraints must fail.

The British experience provides an even stronger case against the "management" theory of restraints. British psychiatrists have found that mechanical restraints are simply not needed in order to manage patients and maintain the therapeutic milieu. In contrast, American "management" practice calls for restraints early and often, encouraging psychiatrists to act immediately rather than to wait and see if the perceived threat materializes.

Some examples of the use of restraints give a flavor of what the "management" theory will justify. In the first a patient is subjected to physical controls for repeatedly lacerating himself superficially to get staff attention; the "treatment" provided a "face-saving way to give up the regressive behavior." In the second, a patient-never actually violent--is restrained for pacing more vigorously than usual. ${ }^{\mathrm{s1}}$ In the third, a patient is

48. See Public Policy Committee of the Royal College of Psychiatrists, Locked Wards and Informal Patients, 4 Bul... Royal. College of Psychiatrists 8, 9 (1980) ("the vast majority of psychiatric patients are cared for and treated in open wards"); MIND, A Practical GuIDE To MENTAL. HEALTH LAW ch. 1 (1983) (90\% admissions "informal;" informal or voluntary patients may leave hospital without notice).

49. No experimental evidence documents the effects of restraints or seclusion. Anecdotal evidence goes both ways, but where studies have been done, physical controls appear in a uniformly bad light.

The most impressive study of how patients in fact react to seclusion (often, seclusion and restraints) is in Wadeson \& Carpenter, Impact of the Seclusion Room Experience, $163 \mathrm{~J}$. Nervous \& MeNTAL DiSF.ASE: 318 (1976). This study was not intended to document the effects of seclusion, thus the danger of patients attempting to please their doctors is minimized. Wadeson and Carpenter found that:

Delusional material and affective response to seclusion directly represent fear, terror, anger,

and resentment. In the art productions, patients presented a universally negative view of the seclusion experience when reacting directly to the event. . . . The nonpsychotic feeling of bitterness over being placed in seclusion was usually a prevailing attitude, even at 1-year followup, not simply an immediate reaction. For a few of our patients, bitterness about being secluded colored their entire perception of their hospitalization.

Id. at 327-28. See also Soliday, supra note 32 (study showing patients have much more negative view of seclusion than staff); Chamberlin, supra note 32, at 288 (ex-patient reports that patients find seclusion form of "torture"); Plutchik, supra note 32, at 575 (study showing patients have largely negative response to seclusion).

50. Wells, supra note 34 , at $412-13$. The patient was secluded.

51. Confidential source in New Haven hospital. 
restrained for being rude to staff. ${ }^{.2}$ The spoon-breaker discussed earlier could be cited under each category: as potentially violent, as agitated, and as disruptive of the milieu. ${ }^{63}$

Professor Wilhelm Griesinger long ago addressed the danger of the argument that the use of restraints is good and only the abuse is blameable. "No one," he said, "can say where the use ends and the abuse begins. ...",54

\section{B. The "Lesser Liberty" Argument}

The second justification for a laissez-faire attitude toward the use of mechanical restraints is that society need not weigh the liberty and dignity interests of psychiatric patients as heavily as it does those of other individuals. Psychiatric patients, the argument might run, cannot appreciate their actions in the way other individuals can. As a consequence, we should be less concerned about protecting their liberty.

This argument fails for two reasons. First, nothing suggests that psychiatric patients do not value and appreciate their freedom at least as much as anyone else does. ${ }^{\mathrm{ss}}$ On the contrary, familiarity with the commitment

52. Binder, The Use of Seclusion on an Inpatient Crisis Intervention Unit, 30 Hosp. \& CoMM. PsychistRy 266, 268 (1979) (also giving examples of patients secluded for yelling at staff, being sarcastic, and refusing medications).

53. Restraints and seclusion may easily be used in inappropriate and untherapeutic ways. See, e.g., Gutheil \& Tardiff, supra note 31, at 14 and 17; Soloff, Physical Controls, supra note 35, at 139-40. The most disturbing cases are those in which restraints seem to be used as a form of punishment. Consider these cases: patient restrained for not getting out of bed (confidential source in Connecticut hospital); not remaining in day area (confidential source in Philadelphia hospital); cutting loose a restrained patient, Soloff, Restraint and the Nompsychotic Patient, supra note 32, at 304; repeated slamming of doors, Mattson \& Sacks, supra note 33, at 1211.

It is true that a number of statutes proscribe the use of restraints as punishment. See, e.g., ILL. Rev. Stat. ch.91 1/2, § 2-108 (1982); LA. Rev. Star. ANN. § 28:17(D) (West Supp. 1986). Yet it is difficult to argue with the claim that restraints were used, not as punishment, but because the milieu was disrupted, or because the patient's "medical needs" called for the use of restraints (i.e. punishment will help him).

The danger that staff will use restraints to meet their own needs (to punish or to manage), whatever the ostensible reason for the restraints, is noted even in the pro-restraints medical literature. Thus Gutheil \& Tardiff, supra note 31, at 16-17, acknowledge that staff may use restraints or seclusion inappropriately to deal with their own problems-to avoid dealing with difficult patients, to engage a distant doctor, or to scapegoat. Binder, supra note 52 , at 268 , notes that seclusion, in his study, appeared sometimes to be used as a method of retaliation.

Guirguis, who disapproves of restraints, points out similar dangers. The habituation potential in staff is too great: restraints may replace more appropriate measures because they are an easy way to handle patients. Similarly, there is the potential for a more profound kind of abuse: "staff can act out their own conflicts by way of punishing the patient." Supra note 32, at 297. See also Strutt, supra note 32 , at 1631 .

54. 300 YeARs, supra note 33, at 1032 (quoting Griesinger's 1867 comment).

55. During the course of personal conversations, a number of psychiatrists have suggested that restraining a mentally ill patient is not like restraining a "normal" person, that mentally ill patients experience being restrained "differently" than would a "normal" person. Conversations with patients who have been restrained, however, strongly suggest that they are no less sensitive to the pain and indignity of being strapped down than any other person would be. 
system, where patients confined involuntarily in hospitals strenuously contest their confinement, may well lead one to precisely the opposite conclusion. ${ }^{B B}$ Second, a standard of liberty based upon an individual's level of functioning would require troubling decisions about the weights and merits of the liberty interests of different individuals and groups in our society. ${ }^{\text {s7 }}$

Indeed, by protecting patients' freedom, society can, first, reinforce in these individuals what freedom they do retain, ${ }^{58}$ second, give these individuals the dignity of making those choices they are in the best position to make, and third, reaffirm its commitment to the dignity and value of each of its members. As a consequence, the decision to restrain a patient, if it is to be made at all, should be made in response to his dangerous actions, not to assumptions about the relative value of his freedom.

\section{The "Intrusion" Justification}

The claim that the law should allow a liberal use of restraints because a more restrictive standard would be too great an intrusion into the medi$\mathrm{cal} \mathrm{milieu}^{\mathrm{bg}}$ fails for two reasons. First, medical regulation of restraints is often not even conceptually sound. Second, no convincing argument has been put forth that a new law governing the use of restraints would make institutional life worse.

We may be wary of intruding too much on medical practice because we think that doctors are best situated to know what their patients need. Thus, we hesitate to burden the profession with extra-medical rules which we fear will not serve patients' interests well. But we often subject medical practice to outside constraints in the belief that patients' needs and interests go beyond the purely medical. ${ }^{\text {Bo }}$

In fact, many decisions to restrain (like decisions to commit) are not medical decisions at all. What degree or imminence of danger justifies restraints? Do the social consequences of mental regression justify re-

56. Interview with Professor Stephen Wizner, Director of Clinical Studies and Professor (Adjunct) of Law, Yale Law School (June 6, 1986).

57. Thus the law seems to shun this kind of argument: in deciding the civil commitment issue in O'Connor v. Donaldson, 422 U.S. 563 (1975), e.g., the Court was not heard to argue that the liberty of mentally ill people was less valuable than that of others. But of. Schall v. Martin, 467 U.S. 253 (1984) (youths' interest in freedom weakened by fact that youths always in someone's custody).

58. See, e.g., Nigrosh, in Assault within Psychiatric Facilities, supra note 32, at 269.

59. This is one of the Court's main concerns in Youngberg v. Romeo, 457 U.S. 307, 322 (1982). It may be some reassurance to note that the non-restraint movement in England, while launched by physicians, was fueled by Parliamentary inquiries in 1815 and 1816, as well as by legislation on restraints some years later. 300 YEARS, supra note 33, at 696-97.

60. I have already discussed how patients must give their informed consent before being treated, and may not be civilly committed solely on the ground that commitment is medically the optimal course. See supra notes 7-13 and accompanying text. 
straints? ${ }^{81}$ These questions implicate acute moral and social values such as the importance of freedom and the rights of the individual against the group. The physician's superior medical knowledge does not vest him with a unique ability to make these collective, ethical choices. The questions are properly social, not medical, and the answers should properly be supplied by social mechanisms. ${ }^{62}$

A second concern with intruding on medical practice within institutions is that it may have unpredictable effects, actually harming instead of improving institutional life. The success of the non-restraint movement in Britain, however, suggests that this fear is unfounded. Moreover, present rules governing the use of restraints ${ }^{68}$ have clearly negative consequences in that they do little to discourage the use of restraints and much to encourage it. Current law credits doctors with predictive powers they do not have $^{64}$ and indulges doctors' fears of liability for injuries they could not have predicted. ${ }^{65}$ As a consequence, current law actually encourages doctors to over-predict violence, and thus to restrain patients unnecessarily. ${ }^{68}$

\section{A Model Restraints Statute}

The abuse of mechanical restraints needs to be addressed in a legislative rather than judicial forum. The recent Supreme Court case of Youngberg v. Romeo $^{67}$ has effectively foreclosed federal constitutional law as a source of controlling the use of restraints, and, if history is any guide, state court

61. See O'Connor v. Donaldson, 422 U.S. 563, 575-76 (1975) for a negative answer to the similar question of whether the vagrant mentally ill can be committed for the sake of the public.

62. Naturally, the precise nature of the distinction between social and medical judgments is unclear. Still, one may at least tentatively call "social" those judgments about people that do not depend on esoteric knowledge of the body or mind.

For an interesting discussion of the distinction between "political" and "medical" decisions, see Gelman, Mental Hospital Drugs, Professionalism, and the Constitution, 72 GEO. L. J. 1725 (1984).

63. Notice that with these existing rules we already intrude into medical institutions. Thus the issue is not whether to intrude, but how to do so in the manner best to protect society's and individuals' interests.

64. See J. Monahan, Predicting Violent Behavior (1981) (psychiatrists wrong in two out of three long-term predictions of violent behavior).

65. For liability for patients injuring themselves, see, e.g., 70 A.L.R.2d 347 (1960); 19 A.L.R.4th 7 (1983). The duty is to exercise such reasonable care for the patients' safety as their mental condition may require. Notice that doctors appear to fear liability more than is warranted. See Kroll \& Mackenzie, When Psychiatrists are Liable: Risk Management and Violent Patients, 34 Hosp. \& CoMm. Psychiatry 29, 29 (1983). Nevertheless, the fear does still govern their behavior.

66. Restraints laws are so loose that liability for inappropriately restraining patients is almost impossible to prove. Moreover, most often the injuries resulting from restraints are dignitary; injured patients may feel it is not worth their while-or the publicity-to sue when an award for damages is not likely to be great.

It might be argued that the present liability scheme is sound, because we are more interested in deterring serious physical injuries than in deterring dignitary violations. But the harms to be compared here are the many serious assaults on dignity and liberty caused by restraints as against the rare physical injury.

67. 457 U.S. 307 (1982) ("professional judgment" standard). 
interpretations of their own constitutions ${ }^{88}$ are likely to follow the federal. ${ }^{68}$ Common law approaches to the problem face a number of serious doctrinal and statutory roadblocks, ${ }^{70}$ and are in any event unable to provide the detailed and certain guidelines which a statute can provide.

\section{A. A Rigorous "Dangerousness" Standard}

A new statute should use a high threshold dangerousness standard. Because the treatment benefits of restraints are highly speculative, a practice so restrictive and degrading as mechanical restraints is justified only in the face of imminent and serious danger. A new statute should therefore state that restraints are permissible only to protect a patient from imminent and serious violence to himself that there is a substantial likelihood of occurring. Examples of serious violence would be significant disfigurement, impairment of bodily function, or grave physical injuries which would require immediate medical attention. ${ }^{71}$

\section{B. Distinguishing Between Restraints and Seclusion}

The second important feature of a new statute should be to distinguish between restraints and seclusion. Of the two, restraints are the more serious deprivation, ${ }^{72}$ and patients overwhelmingly prefer seclusion to re-

68. The mos! powerful state constitutional argument against unnecessary restraint is that liberty is a fundamental interest which should be abridged only for compelling reasons-hence, not for speculative treatment benefits or in the face of minor or remote risks.

69. See, e.g., Note, Developments in the Law: The Interpretation of State Constitutional Rights, 95 HARv. L. R. 1324, 1493-94 (1982).

70. At least three common law arguments are possible: 1) the conventional argument that, absent an emergency, treatment without consent is a battery (but "emergency" can be interpreted weakly enough that many impermissible uses of restraints would be permitted by this argument); 2) a novel argument that restraints decisions should be subject to assessment by a reasonable person standard as to whether the injuries to liberty and dignity are outweighed by the benefits; 3) a similarly novel argument that restraints decisions should be assessed by ordinary battery standards applicable to restraint of the non-ill. All of these arguments could be undermined, however, by the fact that many states statutorily permit restraints for the sake of treatment or to meet patients' "medical needs." See supra note 25 .

71. See similar standard proposed by InSt. Jud. Admin.-ABA Joint Comm'n on Juvenile Justic: Siandards, Srandards Rei.ating to Abuse and Neglect $\S 2.1 \mathrm{~A}$ commentary at 63-65 (1981). The high threshold of danger set forth in this standard for removal of a child from his home seems appropriate in the restraints context for similar reasons: Intervention is only clearly advantageous in extreme situations.

72. Different commentators and states have ranked restraints and seclusion (as well as emergency medication) in different ways, see Wexler, Legal Aspects, supra note 32, at 115-16, although some of these differences may relate to whether medication is used merely as a restraint or also as a form of treatment, whether the restraint is envisioned as public, etc. That reasonable people may differ does not mean that an effort to adopt a presumptive ranking of modalities is misplaced. Indeed, ranking these modalities is made easier now that we know of patients' clear preference for seclusion over restraints. See infra note 73. Doctors' arguments for a different ranking, in light of this preference, are unpersuasive. See, e.g., Soloff, Physical Controls, supra note 35, at 140, who prefers restraints to seclusion because staff can feel less fearful of contact with patients. See also Rosen and DiGiacomo, supra note 32 , at 232 , who inexplicably state that locked seclusion (or even locked wards) cannot be 
straints. $^{73}$ A patient in a seclusion room can walk around, do jumping jacks, lie in a corner; a patient in restraints can do nothing. A patient in restraints suffers the physical pain of forced immobility; a patient in seclusion does not. Finally, restraints are the more severe dignity violation. Nothing in our day-to-day routine prepares us for being strapped down, while being alone in a room-even in a locked room-is a part of most individuals' life experience. ${ }^{74}$

Today, however, restraints are recommended, and are being used, where seclusion would do just as well: for danger to others, agitation, regression, and the preservation of the "therapeutic milieu." No existing statute properly distinguishes between restraints and seclusion. ${ }^{78}$

A model statute, therefore, would confine the use of restraints to when there is an imminent danger of harm to self. ${ }^{77}$ Seclusion can be substituted when there is danger of harm to others, but not to self. The main exception to this rule is triggered when a patient chooses restraints in public over seclusion.

considered less restrictive than restraints, even though they advocate that restraints take place in a solitary room, id. at 228 .

73. See Soliday, supra note 32 , at 284 ( $74 \%$ of patients surveyed think restraints are more unpleasant than seclusion).

74. On the other hand, patients restrained in public, but not secluded, can socialize with others. Observation and discussion with patients suggest that most feel too humiliated to do so, however. This point may be less valid when patients are in less degrading forms of restraint, e.g., restrained unobtrusively to a chair.

Consider further that being restrained to a bed would be impermissible punishment in a prison, because it is too degrading, see supra note 5 . Moreover, $89.4 \%$ of the seclusion/restraints deaths in the N.Y. study were a result of restraints only. See Way, supra note 4.

75. See, e.g., Rosen \& DiGiacomo, supra note 32, at 229-30; Soloff, Physical Controls, supra note 35 , at $135-37$.

76. Fifteen states have a law only on restraints, not on seclusion. Of the states that have laws referring to both, only two have different laws for each. Michigan allows restraints only for safety, Mich. Comp. LAws ANN. $\S 330.1740$ (2) (West 1980), but seclusion if it would be "of clinical or therapeutic benefit for the resident," Mich. Comp. Laws ANN. $§ 330.1742(2)$ (West 1980). Illinois requires a two-day break-unless authorized by the facility director-after 24 hours of restraints, ILL. REv. STAT. ch. $911 / 2, \S 2-108$ (e) (1982). In the case of seclusion the break is to occur after only 16 hours, ILl. Rev. Stat. ch. 91 1/2, § 2-109 (d) (1982). See also Tardiff \& Mattson, supra note 25, at 144 ("Indications for seclusion and restraint were basically the same.").

This legal indifference to the distinction between seclusion and restraints is paralleled by a medical indifference. Some institutions show a clear preference for restraints, others for seclusion, but there is no evidence that the behaviors triggering the different controls are distinguishable. This means that in the former facilities, restraints are often (or always) used where seclusion would be sufficient.

In New York State facilities, for example, $53.6 \%$ of control episodes involved restraints, and $46.4 \%$ involved seclusion. Ten of the thirty one facilities surveyed used only restraints. Way, supra note 3 , Table 6.

77. In addition to using restraints for danger to self, restraints may be used in three further, limited situations: a concurrent medical condition requires an unwilling patient to stay in bed; the medical condition requires an initial physical examination; or it requires physical monitoring more than four times an hour (for the doctor to be non-negligent). On the other hand, if a patient is too violent to be given a mental status exam, then that exam must wait. 


\section{Allowing The Patient Choice}

The third general feature of a new statute should be to give the patient a choice among appropriate control measures, and to require staff to respect his choice. For instance, to avoid extended seclusion (and loneliness), a patient dangerous to others might sometimes choose restraint in the company of other patients instead of seclusion.

It makes sense to give patients a choice among appropriate control measures ${ }^{78}$ even if the patients are of questionable competence, ${ }^{79}$ because doctors have failed to make a persuasive medical case for any particular ranking of these measures. ${ }^{80}$ Furthermore, patients are most likely to know their own states of mind and how the various measures will affect them. In any case, if no ranking can be shown to be objectively better or worse than the others, the patient's choice will never be wrong, and allowing him to choose intrudes less on his liberty and dignity than does imposing one control or another.

To maximize the role patients play in determining which control measure shall be used, they should be advised, on admission, of the advantages and disadvantages of each method. They should be asked to rank these measures in order of 'their personal preference. Any change of heart during an emergency, however, should be respected, and the patient's choice should be sought every half hour he spends controlled.

\section{Procedural Safeguards}

A new statute should also impose a series of procedural requirements to ensure that patients are appropriately restrained and are released once the requisite degree and imminence of danger has passed. First, a doctor should be required to renew her order for restraints each hour, after having personally examined the patient each time. ${ }^{81}$ Second, every two hours

78. Patients dangerous to others should have a choice of medication, seclusion, or restraints in the company of staff or other patients. Patients dangerous to self should have a choice of medication or restraints in the company of staff or other patients. These patients should be told that medication may prove insufficient alone, but may be tried first at their request.

79. But of. Note, Developments, supra note 13, at 1359 n.193 (desirable to give patients choice, but parens patriae patient's choice may be overridden if it does not comport with treatment program).

80. Doctors widely disagree on rankings of measures. Rosen and DiGiacomo prefer restraints, but admit the choice is "subjective." Rosen \& DiGiacomo, supra note 32, at 232. And while Gair thinks physical restraint is, for some patients, too stimulating and diverting, Gair, supra note 32 , at 16, Cubbin regards it as the preferred method, Cubbin, supra note 32 , at 752 . In the absence of a medically supported ranking, patients should be permitted to make their own choice.

81. Three states in the "safety or other rationale" category now require the first type of protection-the order must be renewed every 24 hours. See MONT. CODE ANN. § 53-21-146 (1983); N.J. Stat. ANN. \$ 30:4-24.2(d)(3) (West 1981); S.D. Codified Laws ANN. § 27A-12-6 (Supp. 1986). One state in the "safety or treatment" category also requires renewal every 24 hours. See WIS. STAT. $\Lambda N N$. $\S 51.61(1)(i)(1)$ (West Supp. 1985). Six of the ten "safety only" states require the order to be renewed: Georgia every 24 hours, GA. CODE ANN. § 37-3-165(b) (Supp. 1985); Illinois every 16 
the patient should be released, and should remain out of restraints unless he makes an overt attempt to injure himself. ${ }^{82}$ Third, every fifteen hours the facility director should be required to personally examine the patient, and renew the order for restraints. ${ }^{83}$

In addition, there should be extra-institutional protections. At the end of 24 hours, a legal representative should be required to attend the patient (to inform him of his rights and watch him being released from restraints). At the end of 72 hours, an independent psychiatrist should be required to assess the patient's restraint in the presence of his counsel. If the patient remains in restraints after 72 hours, he should have a hearing before a judge, and should again be represented by counsel. ${ }^{84}$

hours, ILL. REv. STAT. ch. 91 1/2, § 2-108(a) (1982); Kansas every 3 hours (except between 12 a.m. and 8 a.m.), Kan. Stat. ANN. \$ 59-2928 (1983); Massachusetts every 3 hours, Mass. Gen. Laws ANN. ch. 123, § 21 (West Supp. 1985); N.Y. every 4 hours (except between 9 p.m. and 9 a.m.), N.Y. Mental. Hyg. LAW § 33.04(d) (Consol. 1978); see also Tardiff \& Mattson, supra note 25, at 146 (most states have 24 hour time limit; Florida has one hour time limit).

A short initial review time for restraints makes sense, especially in light of Soloff's finding that the duration of seclusion and restraints appears to be independent of patient behavior. See Soloff, Physical Controls, supra note 35 , at 135 .

82. Four states now require release every two hours. In three of the four, it is unclear whether this is to enable the patient to exercise his limbs, or to test his readiness for release. Tardiff \& Mattson, supra note 25 , at 146 . In New York it is to test readiness for release. N.Y. MeNTAL Hyg. LAW \$33.04(f) (Consol. 1978).

83. Off-unit review of the staff's decision to restrain a patient is uncommon, and, even then, often does not require personal examination of the restrained patient. For example, Georgia statutorily requires review by the chief medical officer, but only of a written report. GA. CODE ANN. § 37-3165(b) (Supp. 1985). Illinois requires daily review (of some unspecified kind) by the director of the facility. Il.L. REv. STAT. ch. 91 1/2, § 2-108(d) (1982). See also Tardiff \& Mattson, supra note 25, at 146 (nine states require off-unit review of some kind after 24 hours, three states, after eight hours).

84. The experience of New York, the state with one of the strictest restraints laws, suggests that, with adequate and frequent checks, prolonged restraint is minimized. Thus, in a one-month study in New York, most restraints orders were for four hours (the length before required physician review) followed by a large minority which were for two hours (the length before test-release). Way, supra note 3, at Table 8 . Moreover, $95.5 \%$ of the patients were restrained no longer than four hours, with most of these under two hours. Id. at Table 9.

Nevertheless, the first two procedures are insufficient to keep restraints within reasonable bounds. Consider that $2 \%$ of the cases in the New York study were restraint episodes of nine hours or more, and $1 \%$ were episodes of twelve hours or more. Id. at Table 9. Moreover, the figures are for patients restrained six or fewer times in the month studied. Patients restrained over six times were likelier to receive orders for nine hours or more ( $11 \%$ vs. $2 \%$, id. at $4 ; 24 \%$ vs. $16 \%$ in one facility, id. at 5$)$, and these individuals accounted for $39 \%$ of all episodes of restraint or seclusion. Id. at 1.

Connecticut provides examples of prolonged restraint as well. One doctor candidly acknowledges that he restrains patients, on occasion, for several weeks at a time (confidential source in New Haven hospital). Another hospital has restrained a small girl, whenever she is not in locked seclusion, for over two years (confidential source in New Haven hospital).

The last three procedural protections are therefore offered as failsafe measures, to protect patients from the prolonged restraint which now occurs, and which is legally permitted in many states. Only the first has even a rough parallel in existing law: ILL. REv. STAT. ch. $911 / 2, \S 2-201$ (c) (1982) (notice to the "Guardianship and Advocacy Commission" if the patient desires).

The use of independent psychiatrists to review restraints episodes would be perhaps less costly than might at first appear, for some states are now adopting regulations on medication refusal which call for or authorize evaluation by independent psychiatrists. See, e.g., N.J. Ad. Bull. 78-3 § II(E)I; Ohio Department of Mental Health, Policy on Client Participation in Medication Decisions 18-19 (June 13, 1984); 25 TEx. Admin. CoDE tit. 25, $\S 405.808$ (6) (1984). The same is true for representation. 
While requiring such an extensive set of procedures would be costly, ${ }^{85}$ the hope is that the costliness of the procedures-as well as the high degree of danger required-will deter the use of restraints in all but the most exigent circumstances.

\section{E. Liability Limits For Doctors}

To redress the flaws of the existing liability scheme, a new principle of liability should be designed to deter doctors from using restraints out of a fear that malpractice suits will be brought. Liability should be strengthened for unreasonably restraining patients. ${ }^{86}$ Doctors, however, should not be held liable for injuries resulting from a failure to restrain patients, unless a person of the most common understanding ${ }^{87}$ would have foreseen serious injuries of the kind described in the statute. ${ }^{88}$

This principle of liability ${ }^{80}$ recognizes the limits of doctors' ability to

See, e.g., Michigan Administration of Psychotropic Medication, supra note 22; N.Y. ADMIN. Code tit. 14, § 27.8 (d) (1984) (attorney or other "concerned person"); Ohio Department of Mental Health, Policy on Client Participation in Medication Decisions 12 (June 13, 1984).

85. Note that while the proposed procedures are designed especially to protect against the prolonged use of restraints, all but the last should also be in force whenever the total length of time a patient spends in separate periods of restraint, within 30 days, equals the specified number of hours. When a patient spends 72-120 non-successive hours in restraints, a hearing should be provided only if his representative alleges an impermissible use of restraints. When he spends more than 120 nonsuccessive hours in restraints, a hearing should automatically be provided.

Note also that if a patient is claimed to have consented to treatment by restraints, he should nonetheless be seen after 15 hours by the facility director to ensure that the consent is genuine and competent, and similarly by the patient advocate after 24 hours. Patients are often said to go "willingly" into restraints when they do not resist, even if they have been presented with a show of force and given no alternative. The patient advocate should determine whether review by an independent psychiatrist or the court is warranted.

86. For example, one could establish some specific damages for violating the statute; these would have to be set not so high as to risk jury nullification, nor so low as to become merely a cost of doing business. Alternatively, one could raise a presumption of a battery for violation of the statute, to be rebutted only by a showing that extraordinary circumstances existed.

87. Compare McCall v. McDowell, 15 F. Cas. 1235, 1240 (C.C.D. Cal. 1867) (obeying superior's commands defense to illegal action unless person of the most common understanding would know command illegal).

Other ways of weakening liability for injuries resulting from failure to restrain a patient would be to put a cap on damages or to use a "gross negligence" standard. But the former penalizes doctors for proper behavior-i.e. waiting to restrain a patient until the danger is patent-and protects doctors for improper behavior-i.e. not restraining a patient when the danger is patent. And the latter misleadingly implies that waiting to restrain a patient until the danger is patent is negligent.

88. This is not to say that failing to use measures short of restraints-e.g. restricting a patient to a lounge, "specialling" a patient-would not subject a doctor to liability unless a person of the most common understanding would predict violence; on the contrary, an "ordinary doctor" standard would be used in such a case.

89. There are other situations in tort law in which the standard of care is lowered in order that concerns about malpractice not govern physicians' actions. The most notable is the situation covered by "Good Samaritan" laws. These attempt to encourage physicians (and others) to intervene to help a person toward whom no duty of care was owed at common law. Most such statutes hold a physician who so intervenes liable for injuries caused only by "gross negligence," or some similar form of misconduct. See Mapel \& Weigel, Good Samaritan Laws-Who Needs Them? The Current State of Good Samarilan Protection in the United States, 21 S. TEx. L. J. 327, 342-46 (1981); Note, Good 
predict violence. It eases the pressure on doctors who may feel besieged by conflicting demands-both to protect patients and not to restrain them-by making a clear value-choice: Great numbers of patients should not be restrained in order to protect against the rare occurrence of selfinflicted injury.

Most importantly, the rule is designed to reduce both the use of restraints and the supervention of patients' choices. The fear that, if effective, the rule would cause a dramatic rise in self-injuries is unfounded, as may be seen from the situation in England. A serious increase in the use of other controls also need not occur: English doctors have not significantly resorted to seclusion or medication to compensate for not using mechanical restraints.

In America, a proposed restraints law may eventually have to be supplemented by a seclusion and emergency medication law. In the meantime, a new statute would spare some patients the pain of unnecessary restraint. Given the grave injury to individual liberty and dignity caused by restraints, that alone would be well worth achieving.

Samaritan Statutes: Time for Uniformity, 27 WAyne L. REv. 217, 224-25 (1980). The idea of such a lower standard, as in the case of the restraints law, is to encourage physicians to act (or not act) by lowering the risks of malpractice consequent upon their action (or inaction).

Consider also the area of constitutional torts, where an objective standard of qualified immunity limits government actors' liability so as to encourage vigorous decision-making. For the standard, see Harlow v. Fitzgerald, 457 U.S. 800 (1982). On appropriate incentives for government actors, see P.

SCHUCK, SuING GovernMENT (1983). 